\title{
Download
}

UDC 911.9:504. 379.851(075.8):062.2

Kalko Andriy Dmytrovych, doctor of geography, professor, International University of Economics And Humanities Academician Stepan Demianchuk, Rivne, Ukraine, e-mail:

edissey@meta.ua

Myronets Nina Rostyslavivna, Candidate of Historical Sciences, Associate Professor, Internatio nal University of Economics and Humanities Academician Stepan Demianchuk Rivne, Ukraine, e-mail:nina_myr@ukr.net

Basiuk Tetiana Oleksandrivna, Candidate of Geographical Sciences, International University of Economics and Humanities Academician Stepan Demianchuk, Rivne, Ukraine, e-mail: tanya_basyuk@ukr.net

Guiltyuk Vadim Mykolajovych, International University of Economics and Humanities Academician Stepan Demianchuk 


\section{EXPLOITATION OF THE ROYAL DEPOSIT OF DACITES (STRUCTURAL AND GEOGRAPHICAL ASPECTS)}

Purpose - constructive-geographic generalization of the stock status of the Royal deposit of dacites.

Method. The study uses methods of processing geographic information: system analysis, landscape, ecological, cartographic, historical, descriptive, comparison and forecasting, principles of optimization of the natural environment. The analysis and calculation of the remnants of the previously explored reserves of dacites of the Royal deposit was carried out.

Results. Physical and mechanical tests of dacites of the Royal deposit were performed. To study the hydrogeological conditions of the deposit of dacites below the $130 \mathrm{~m}$ mark, drilling of a hydrogeological well with a depth of $50 \mathrm{~m}$ was performed and a test run of water was made at one level down. According to the study, the balance of previously investigated reserves of dacites of the Royal deposit is 921.3 thousand $\mathrm{m}$ ${ }^{3}$, which corresponds to the data of the mine surveying service of the quarry on residual balance reserves. It was established that the total reserves of the field dacites together with the well-known plot are 9061.5 thousand $\mathrm{m}$ 3

. The remainder of dacite reserves prepared for extraction is 1512 thousand $m$ 3

. The volume of useful minerals in the major part of the deposit is 591.5 thousand $\mathrm{m}$ 3

Scientific novelty. The peculiarities of methodological approaches to the investigation of dacites of the Korolivsky deposit are analyzed. The prospects of ecological and economic use of dacites of the Royal deposit are substantiated. 
Practical significance. It is established that the quality of raw materials of the Royal deposit of daciots, including the part of the current site, is rather stable. By degree of exploration, the reserves of dacites in the most famous area of the Royal deposit are classified as category A.

Key words: deposit, volcanic rocks, useful component, openings, open development.

References

1. Report on the state of the environment of the Transcarpathian region for 2016 // Department of Ecology and Natural Resources: Uzhgorod, - 2016. - 158 p.

2. Rzhevsky V.V. Open mountain work. Ch. 1. - M .: Nedra, 1985. - 510 p.

3. Branch "Korolitsky special cary" [Electronic resource]. - Access mode: https://clarity-project.i nfo/tenderer/05471804.

4. Environmental passport of the Transcarpathian region // Department of Ecology and Natural Resources of the Transcarpathian Regional State Administration: Uzhgorod. - 2017 - 104 p.

5. Kalko A.D. The problems of exploitation of the Korolevo deposit of dacites / A.D. Kalko, Y. M. Deyak

V.I. Turok

L.I. Guranich

/I

A

bstracts of speeches of the International scientific-practical conference

6. «Problems and prospects of higher education and economy development in the XXI century $》(11-22$

October

2018). - 
v4812

Written by Administrator

Tuesday, 26 May 2020 12:29 - Last Updated Thursday, 28 May 2020 16:53

\section{Rovno}

, 2018. -

$\mathrm{P}$

$.289-291$ 